\title{
Pengaruh Suplementasi Probiotik Melalui Pakan terhadap Konsumsi Pakan Ayam Petelur Strain Isa Brown
}

\section{Effects of Probiotic Supplementation Through Feedon the Feed Consumption of Layers Strain Isa Brown}

\author{
Dian Afikasari ${ }^{1}$, Rifa $^{\prime} \mathbf{i}^{2 *}$ dan Diyah Ayu Candra ${ }^{3}$ \\ 1,2,3 Program Studi Peternakan, Fakultas Peternakan, Universitas Kahuripan Kediri Jl. \\ Soekarno Hatta, No. 01 Pare 64213, Kediri, Jawa Timur, Indonesia \\ *Corresponding authorl:rifai01askaf@gmail.com
}

Sejarah artikel : Menerima : 22 Juni 2020 Revisi : 25 Juni 2020 Diterima : 29 Juni 2020 Online : 30 Juni 2020

\begin{abstract}
ABSTRAK
Penelitian ini bertujuan untuk mengetahui pengaruh konsumsi pakan pada ayam petelur melalui penambahan probiotik pada pakan ayam. Suplementasi probiotik Lactobacillus acidophilus dan Bifidobacteria sebagai alternatif dari Antibiotic Growth Promoter (AGP) yang berpengaruh dalam konsumsi pakan ayam petelur. Penelitian ini melibatkan 180 ayam petelur pada usia 35 minggu sepenuhnya diacak menjadi tiga perlakuan. Perlakuannya adalah T0 yakni berisi pakan standar, kemudian T1 berupa pakan standar dengan 0,1 g/120 g pakan AGP, dan T2 pemberian 2,5 ml probiotik Lactobacillus acidophilus $+0,5 \mathrm{ml}$ Bifidobacterium yang dicampurkan dengan pakan standar

$120 \mathrm{~g} / \mathrm{ekor} / \mathrm{hari}$. Hasil penelitian memperlihatkan perbedaan yang signifikan antara perlakuan $(\mathrm{p}<0,05)$. Konsumsi pakan tertinggi yaitu pada T0 115,14 gram/ekor/ hari, kemudian T1 menunjukkan hasil konsumi pakan 113,19 gram/ekor/hari, dan T2 menghasilkan konsumsi pakan terendah yakni 112,16 $\mathrm{gram} / \mathrm{ekor} /$ hari. Hasil penelitian menunjukan terjadi penurunan konsumsi pakan dikarenakan pemberian probiotik yang menjadikan efisiensi proses pencernaan pada ayam petelur.
\end{abstract}

Kata Kunci : AGP, Probiotik, Konsumsi Pakan

The purpose of this research is to determine the effect of feed consumption on the layers Strain Isa Brown through the supplementation of probiotics in feed. Supplementation of Lactobacillus acidophilus and Bifidobacteria as an alternative to Antibiotic Growth Promoter (AGP) uses the consumption of layers. The study used 180 layers at 35 weeks of age completely randomized into three treatments. The treatment is TO which contains standard feed, then T1 is standard feed with $0,1 \mathrm{~g} / 120$ $g$ feed AGP and T2 standard feed with $2,5 \mathrm{ml}$ Lactobacillus acidophilus $+0,5 \mathrm{ml}$ Bifidobacterium diluted with standard feed $120 \mathrm{~g} / \mathrm{head} / \mathrm{day}$. The results showed that there were significant differences between treatments $(p<0.05)$. The highest feed consumption is at TO 115.14 grams/head/day, then $T 1$ shows the consumption of $113.19 \mathrm{grams} / \mathrm{head} /$ day and T2 produces the lowest feed consumption of $112.16 \mathrm{grams} / \mathrm{head} /$ day. The results showed a decrease in feed consumption due to the provision of probiotics which makes the efficiency of the digestive process in layers.

Key word : AGP, Probiotics and Feed Consumption

\section{PENDAHULUAN}

Telur merupakan bahan pangan yang memiliki sumber protein hewani dengan gizi tinggi dan lezat. Selain itu telur merupakan bahan makanan yang paling sering dikonsumsi oleh masyarakat karena harga relatif murah dan mudah diperoleh (Hasym, 2016).
Sektor usaha ayam petelur di Indonesia mengalami banyak kendala, diantaranya yang dihadapi peternak adalah tidak stabilnya harga telur ayam sedangkan harga pakan cenderung meningkat. Hal ini mengakibatkan pendapatan yang diterima tidak sebanding dengan biaya pakan. Faktor pakan dalam usaha ternak ayam 
petelur mencapai nilai $60-70 \%$ dari total biaya produksi. Peternak dapat menekan biaya produksi apabila terdapat peningkatan efisiensi pakan. Saluran pencernaan ayam yang bekerja optimal dalam mencerna serta menyerap zat makanan dapat menghasilkan efisiensi pakan yang tinggi sehingga terjadi peningkatan produktifitas ayam petelur.

penggunaan antibiotik menimbulkan efek samping bagi konsumen yang sering mengonsumsinya (Prawitya dkk, 2014). Penambahan Antibiotic Growth Promoter (AGP) dengan dosis yang relatif sedikit dapat meningkatkan efisensi pakan (Daud dan Kompiang, 2007)

Potensi bahaya dari bahan pangan yang mengandung residu antibiotik digolongkan menjadi 3 aspek yaitu mikrobiologis, toksikologis dan imunopatologis (Hintono dkk, 2007).

Larangan penggunaan AGP dalam industri perunggasan, maka disarankan bahwa probiotik sebagai alternatif penganti AGP (Kannan et al., 2005). Probiotik yaitu mikrooragnisme yang apabila dikonsumsi ternak dalam bentuk sel kering ataupun produk fermentasinya dapat meningkatkan kesehatan (Ouwehand, 2017).

Lactobacillus sp dan Bifidobacterium sp memproduksi beberapa metabolit yakni hydrogen peroksida, bakteriosin dan asam laktat, yang dapat membunuh bakteri pathogen dan menghambat pertumbuhan. Probiotik dapat melawan mikroba pathogen dengan mekanisme kompetisi adesi di sel epitel, kompetisi dalam penggunaan nutrisi serta mampu meningkatkan sistem tubuh inang. (Lourens dan Valjoen, 2001). Pada penelitian yang dilakukan Wahyuni (2014) dilaporkan bahwa aktivitas antibakteri dalam sediaan susu yakni probiotik Bifidobacterium bifidum dan Lactobacilus acidophilus menghasilkan zona hambat terhadap bakteri E.coli, S. typhimurium dan $V$. Cholerae.

\section{MATERI DAN METODE}

Pelaksanaan penelitian di peternakan Unggul Jaya Farm, Desa Nambakan Kabupaten Kediri. Materi penelitian yang digunakan adalah 180 ekor ayam petelur fase petelur umur 35 minggu, ayam petelur strain Isa brown dari PT. Charoen Pokhpand. Penelitian ini ekperimental, menggunakan Rancangan Acak Lengkap (RAL) diacak menjadi 3 perlakuan (P0, P1, P2) dengan 6 ulangan, setiap ulangan menggunakan 10 ekor. Perlakuan dilaksanakan selama 1 bulan.

Susunan ransum pakan ayam beserta kandungan nutrisi yang digunakan dapat dilihat pada tabel 1 .

Tabel 1. susunan ransum dan kandungan nutrisi

\begin{tabular}{lclllll}
\hline Sampel & Bahan Kering (\%) & Abu (\%) & Protein $(\%)$ & Lemak $(\%)$ & Serat Kasar $(\%)$ & Ca (\%) \\
\hline Jagung & 87.2219 & 1.6768 & 9.0516 & 3.9687 & 2.993 & 0.1832 \\
Dedak & 90.5503 & 9.9614 & 11.9698 & 12.1221 & 13.5416 & 0.4271 \\
Konsentrat & 93.6765 & 32.9428 & 32.1617 & 9.6372 & 5.2158 & 9.5987 \\
Pakan jadi & 90.1184 & 14.5487 & 18.5444 & 6.5997 & 6.7108 & 5.0572 \\
\hline
\end{tabular}

Sumber : Hasil Uji Proksimat di Lab. Pakan FKH Universitas Airlangga (2018).

\section{HASIL DAN PEMBAHASAN}

Penelitian ini menunjukkan hasil bahwa perlakuan dari P0 yaitu 100\% pakan basal tanpa probiotik dalam pakan, P1 yaitu pakan basal ditambah 0,1 gram AGP/ kg pakan, P2 yaitu $0,25 \%$ Lactobacillus acidophilus $+0,5 \%$ Bifidobacterium yang dicampurkan dalam pakan ayam, terhadap konsumsi pakan ayam

\section{Hasil Konsumsi Pakan Ayam}

Konsumsi pakan di penelitian ini diperoleh dengan cara mengurangi data jumlah pakan yang diberikan dengan data jumlah sisa pakan yang tidak termakan oleh ayam. Rataan dan simpangan baku konsumsi pakan pada ayam petelur dalam satu bulan ditunjukkan pada tabel 2.

Tabel 2. Rataan dan Simpangan Baku Dari Hasil Pengamatan Konsumsi Pakan Ayam Petelur (gram/Ekor/hari) dalam Satu Bulan.

\begin{tabular}{cc}
\hline Perlakuan & Konsumsi Pakan ayam (g/ekor/hari) \\
\hline P 0 & $115.14^{\mathrm{a}} \pm 0,048$ \\
P 1 & $113.19^{\mathrm{b}} \pm 0,070$ \\
P 2 & $112.16^{\mathrm{c}} \pm 0,089$ \\
\hline
\end{tabular}

Keterangan : ${ }^{a, b, c}$ Superskrip memperlihatkan hasil perbedaan yang nyata $(p<0,05)$.

Penelitian dalam waktu satu bulan menunjukkan hasil bahwa diantara perlakuan menperlihatkan hasil adanya perbedaan yang nyata $(p<0,05)$. Pada perlakuan yang tidak 
diberi probiotik maupun AGP yakni PO menunjukkan konsumsi tertinggi. Kelompok perlakuan P1 yang diberi AGP dengan pakan basal menunjukkan hasil konsumsi lebih rendah daripada perlakuan PO. Konsumsi pakan perlakuan P2 dengan pemberian probiotik menghasilkan konsumsi terendah. Setiap perlakuan diberi 6 ulangan, sedangkan untuk masing-masing ulangan mengunakan 10 ekor ayam petelur. Pengamatan dilakukan selama 1 bulan.

Hasil penelitian ini sudah sesuai standar Management Guide Lohman Brown yakni konsumsi ayam petelur pada saat periode produksi sebesar 110-120 gram/ekor/hari. Konsumsi pakan tertinggi pada perlakuan PO yaitu 115.14 gram/ekor/harisedangkan P1 hasilnya lebih rendah dari perlakuan P0 dan perlakuan P2 memiliki konsumsi pakan terendah yaitu 112.16 gram/ekor. Perbandingan konsumsi dari tiap perlakuan dapat dilihat pada gambar 1 .

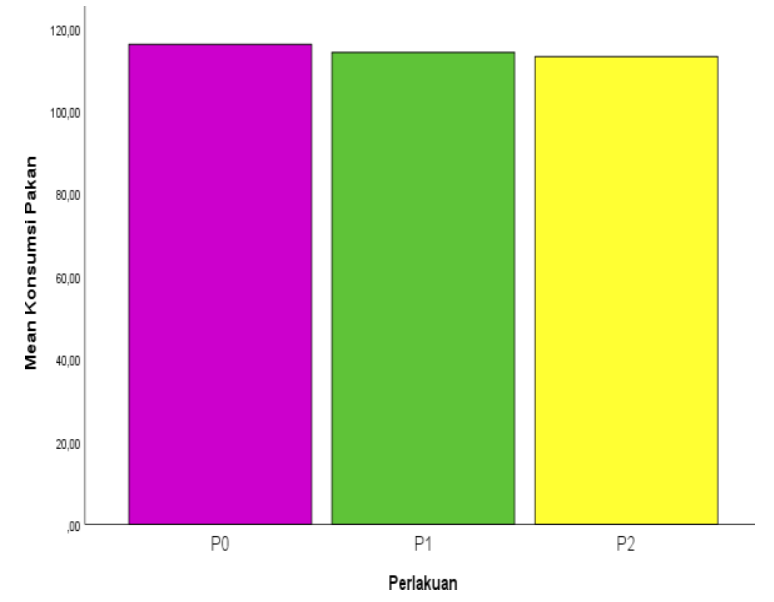

Gambar 1. Perbandingan Konsumsi Pakan

Di penelitian ini, probiotik memiliki peran didalam saluran pencernaan untuk memperbaiki dan meningkatkan kecernaan pada pakan yang dikonsumsi dengan bantuan bakteri yang bersifat menguntungkan (Kompiang, 2002). Hal ini, akan mengakibatkan laju pergerakan makanan dalam saluran pencernaan lebih cepat, sehingga zat-zat makanan lebih banyak terserap dan efisisensi penggunaan pakan serta laju produksi meningkat (Suherman, dkk., 2015). Dengan demikian penggunaan probiotik pada ayam petelur dapat menurunkan konsumsi pakan dengan efisiensi yang baik.

Lactobacillus acidophilus,memiliki hubungan positif dengan mukosa usus unggas. Lactobacillus acidophilus memperkuat sistem pertahanan mukosa usus selain itu Lactobacillus acidophilus memiliki aktivitas anti- inflamasi (Alterman et al., 2005). Pada penelitian yang dilakukan Getachew (2016)
Suplementasi kombinasi spesies Lactobacillus (L. acidophilus dan $L$. plantarum) dapat meningkatkan Feed Intake (FI), Hen Day Product (HDP) dan Egg weight. Lourens dan Valjoen (2001) menjelaskan bahwa Lactobacillus sp dan Bifidobacterium sp mampu menghasilkan beberapa metabolit yang bermanfaaat dalam pencernaan yaitu : asam laktat, hydrogen peroksida dan bakteriosin dengan kemampuan menghambat bakteri pathogen. Bertambahnya ketersediaan nutrisi di dalam saluran pencernaan memberikan efek terhadap konsumsi dan produksi telur menjadi lebih efisien. Tercukupinya nutrisi didalam saluran pencernaan menyebabkan konsumsi pakan menjadi lebih rendah (Natalia dkk., 2016). Penambahan mikroba yang menguntungkan bagi ternak dapat meningkatkan pencernaan makanan, sehingga dapat mengefisienkan konsumsi pakan (Astuti dkk., 2015).

Kelompok perlakuan P2 menunjukkan hasil konsumsi yang lebih rendah daripada perlakuan P1 dan P0. Hasil ini sejalan dengan hasil penelitian Yan et al., (2017) bahwa pemberian probiotik pada pakan, disarankan untuk menggunakan Lactobacillus untuk meningkatkan efisiensi pakan. Hasil ini juga didukung dengan hasil penelitian dari Herlinae dan Yamina (2016) bahwa efisensi pakan dapat dicapai dengan pemberian probiotik.

\section{KESIMPULAN}

Hasil penelitian menunjukan terjadi penurunan konsumsi pakan dikarenakan pemberian probiotik yang menjadikan efisiensi proses pencernaan pada ayam petelur.

\section{PUSTAKA}

Astuti, F.K., Busono W. dan Sjofjan O. 2015. Pengaruh Penambahan Probiotik Cair dalam Pakan terhadap Penampilan Produksi pada Ayam Pedaging. Jurnal Pembangunan dan Alam Lestari. 6(2): 99-104.

Daud, M. Piliang dan Kompiang P. 2007 Persentase dan Kualitas Karkas Ayam Pedaging yang Diberi Probiotik dan Prebiotik dalam Ransum. JITV 12 (3): 167174.

Getachew, T., Hawaz, E., Ameha, N., and Guesh., T. 2016. Effect of Probiotic Lactobacillus Species Supplementation on Productive Traits of White Leghorn Chicken. Journal of World Poultry Research. 6(4): 199204.

Hasym, A. (2016). Pengaruh Perendaman dalam Ekstrak Teh Hitam dan Teh Hijau (Camelia sinensis) terhadap Kadar Antioksidan pada Telur Asin. Skripsi. 
Fakultas Pertanian Peternakan UMM, Malang.

Hintono, A., Astuti, M., Wuryastuti, H. dan Rahayu E. S,. 2007. Residu Oksitetrasiklin dan Aktivitas Antibakterinya dalam Telur dari Ayam yang Diberi Oksitetrasiklin dengan Dosis Terapeutik Lewat Air Minum. Universitas Diponegoro.

Kannan, M., Karanakaran R., Balakrishnan V. and Prabhakar T.G. 2005. Influence of Prebiotics Supplementation on Lipid Profile of Broilers. International. Journal of Poultry Science. 4(12): 994-997.

Komala, I. 2008. Kandungan Glzi Produk Peternakan. Student Master animal Science, Fac. Agriculture-UPM.

Kompiang, I.P. 2002. Pengaruh ragi: Saccharomyces Cerevisiae dan Ragi Laut sebagai Pakan Imbuhan Probiotik terhadap Kinerja Unggas. JITV. 7(1):18- 21.

Lourens-Hattingh A., Viljoen B C. 2001. Yoghurt as Probiotic Carrier Food. International Dairy J. 11: 1-17.

McDonald, P., Edwards R. A., Greenhalgh J. F. D. and Morgan C. A. 2002. Animal Nutrition. 5th Edition. Longman Scientific and Technical. New York.

Natalia, D., Suprijatna E and Muryani R. 2016. Pengaruh Penggunaan Limbah Industri Jamu dan Bakteri Asam Laktat (Lactobacillus sp.) sebagai Sinbiotik untuk Aditif Pakan terhadap Performans Ayam Petelur Periode Layer. Jurnal IImu-IImu Peternakan. 26(3): 613.

Ouwehand, A.C. 2017. A Review of DoseResponses of Probiotics in Human Studies. Beneficial Microbes. 8(2): 143-151.

Prawitya, A. S., Natsir M. H dan Sjofjan, O. 2014. Effect Of Addition Probiotics Lactobacillus sp. Powder in Feed On the Laying Hens Performances. Animal Nutrition and Feed Departement. Faculty Of Animal Husbandry. Brawijaya University.

Riboty, R., Chamba F., Puyalto M. and Mallo J. J. 2016. Effect of Partially- Protected Sodium Butyrate and Virginiamycin on Nutrient Digestibility, Metabolizable Energy, Serum. International Journal of Poultry Science. 15 (8): 304-312.

Suherman, A.F., Natsir M.H. dan Sjofjan O. 2015. Pengaruh Penambahan Probiotik Lactobacillus Plus Bentuk Tepung Sebagai Aditif Pakan Terhadap Penampilan Produksi Burung Puyuh. JITV. 1-8.

Susilorini, T. E., Sawitri, M. E., dan Muharlien. 2008. Budidaya 22 Ternak Potensial. Penebar Swadaya, Jakarta.

Wahyuni R., Isnaeni., Darmawati A. 2014. Prospektif Kombinasi Susu Probiotik Lactobacillus Acidophilus dan
Bifidobacterium bifidum Sebagai Sediaan Anti Diare.

Yan, W., Sun C., Yuan J. and Yang N. 2017. Gut Metagenomic Analysis Reveals Prominent Roles of Lactobacillus and Cecal Microbiota in Chicken Feed Efficiency. Scientific Reports. 7: 45308. 